\title{
濃縮試験における尿渗透圧
}

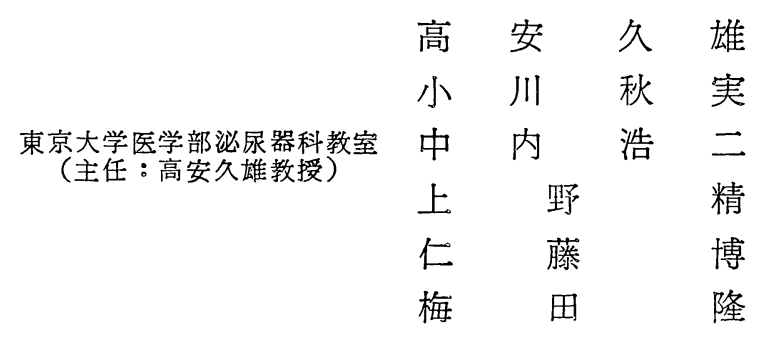

\section{MAXIMAL URINE OSMOLALITY}

Hisao Takayasu, Akimi Ogawa, Koji Nakauchi, Akira Ueno, Hiroshi Nito and Takashi Umeda

From the Department of Urology, Faculty of Medicine, the University of Tokyo

(Director: Prof. H. Takayasu)

Urine osmolalities following the Fishberg concentration test were determined in 192 consecutively admitted patients.

The following results were obtained.

1) A linear relationship was found to exist between the urine osmolality and the urine specific gravity, with a correlation coefficient of 0.7 .

2) The first urine specimen following the test showed higher osmolality than the other two specimens in one fourth of cases.

3) The maximal urine osmolality following the test was not always reproducible.

4) A lower limit of the maximal urine osmolality obtained statistically in patients with normal renal function was about $700 \mathrm{mOsm} / \mathrm{kgH}_{2} \mathrm{O}$

A progressive decrease with age was found in the maximal urine osmolality.

5) The maximal urine osmolality was reduced in patients with lower urinary tract obstruction, with bilateral renal disease and with adrenal disease.

6) Parallel with the elevation of serum urea nitrogen, the maximal urine osmolality was lowered.

7) No distinct relationship was found to exist between the maximal urine osmolality and the PSP excretion. However, the maximal urine osmolality showed a tendency to decrease according as the PSP excretion became impaired.

8) The maximal urine osmolality was found to be lower after surgical procedure than before.

\section{緒言}

濃縮試験は古くより臨床的に行われている腎機能検査

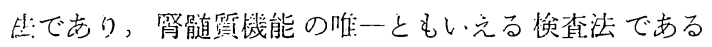
が，尿渗透圧の測定が困難であつたため，比重測定で代 用せられて来た。その上，比重測定自体の精度の低さ と, 比重と渗透圧とは必しも併行しないため, 腎髄質機 能の病態生理の追求は, クリアランス法を主とした腎皮 質機能の研究に比し，些方遅机た憾があつた。
然し, 腎濃縮機構がカウンターカレント系によること が動物実験で実証せら机 ${ }^{11}$, 臨床面でも腎病態生理の解

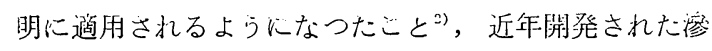
透圧計が容易にかつ精度の高い測定を可能にしたことの ため ${ }^{3) 4)}$, 濃縮試験の重要性が再認識されている。

濃縮試験を滲透圧の面より検討した報告は, 本邦では 殆んどみられない。

吾々は入院患者に施行した濃縮試験に基き, 以下の項 
目について検討したので報告する．

1）尿渗透圧と尿比重との相関

2） Fishberg 氏濃縮試験の三分尿のいずれが最高尿滲 透圧を示すか.

3）最高尿渗透圧の再現性.

4）最高尿滲透圧の正常範囲および年令による変化.

5）最高尿滲透圧の疾患による変化.

6）最高尿滲透圧と血清尿素窒素值との関俰.

7）最高尿滲透圧と PSP 排泄試験との関係

8）最高尿渗透圧の手術前後の変化.

\section{検查対象}

昭和39年11月より昭和 40 年 5 月迄の 6 カ月間に東大泌 尿器科に入院した 192例で, 男子 139名, 女子52名, 真 性半陰陽 1 名である。

\section{検查方法}

入院時と退院時に濃縮試験を施行したが, 方法は Fishberg 氏法を若干変更したもので, 夜 6 時乾燥食摂取後 领食を禁じ，翌朝 5 時覚醒とともに採尿，次いで 1 時間 後执よび 2 時間後に採尿するものである．なを，病室の 温度は約 $25^{\circ} \mathrm{C}$ の恒温である。

採取した尿は，滲透圧計（Fiske Mark 3) により滲透 圧の測定, 臨床屈折計 (Elma) 飞よる比重の測定, 及 び栄研ウロペーパーAによる蛋白の定量を行つた.

\section{結果並びに考按}

\section{1）尿滲透圧と尿比重との相関（図 1，図 2）}

各測定結果を尿蛋白の有無で分け，尿渗透圧と屈折計 で測定した尿比重との相関をみると，蛋白の有無に拘ら ず殆んど直線の相関を示し，相関係数は約 0.7 である が，渗透圧の高い法らで相関の弱い傾向がある．尿蛋白 陽性の場合は若干ばらつきが大きい。

な特，尿比重は 1.040 以上は読みとれないため，以上 の計算では除外した.

一定滲透压に対する比重の分布をみると，ばらつきが 大きく，例えば $800 \mathrm{mOsm} / \mathrm{kgH}_{2} \mathrm{O}$ では 1.021 から 1.0 32にまで分散している。諸家の報告でも，渗透圧と比重 の相関は良好ではな(5) 10).

尿渗透圧は尿の溶質のモル濃度を示し，尿比重は尿の 溶質の重量濃度に関係するものである，尿中の溶質は各 種の物質で種々の割合よりなつているため，両者の間に 完全な相関がないのは当然である.

腎での尿濃縮は渗透圧勾配により水の再吸収が行われ ることであるため, 濃縮機能の表現には, 比重よりも渗
図 1 尿渗透圧と尿比重の相関 尿蛋白（一)

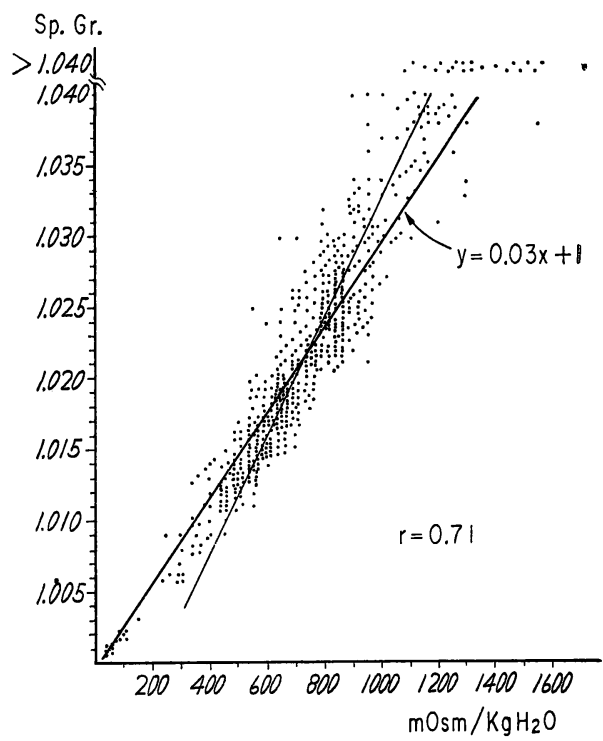

図 2 尿渗透圧と尿比重の相関 尿蛋白 $>15 \mathrm{mg} / \mathrm{dl}$

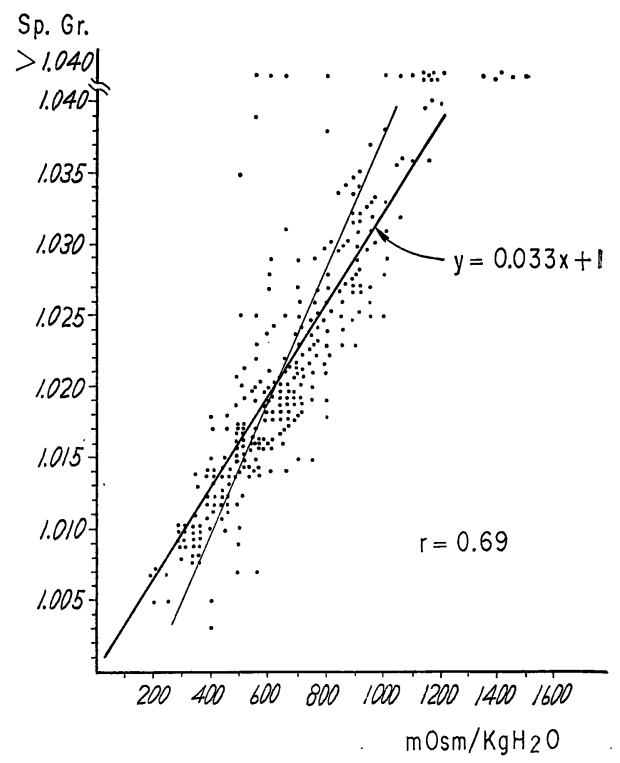

透圧を直接あらわすモル濃度が合理的である。

比重測定には，従来浮秤式の比重計が用いられてきた が，誤差が大きく，特に濃縮試験では尿量が減少するた めに, 浮秤式比重計では定量が殆んど不可能と考えてよ い.

な怙，吾々は以前より小量の尿の比重測定に屈折計を: 
表 1 濃縮試験に打子 3 分尿の尿滲透圧濃度 の順位（入院時）

\begin{tabular}{|c|c|c|c|c|c|c|c|c|}
\hline 濃度 & 堅 & \begin{tabular}{|l} 
偏腎 \\
疾患
\end{tabular} & $\begin{array}{l}\text { 下部尿塞 } \\
\text { 路閉性疾艒 }\end{array}$ & 両腎 & 副腎 & 神経因 & 小計 & 計 \\
\hline $\begin{array}{l}321 \\
312\end{array}$ & $\begin{array}{l}9 \\
6\end{array}$ & $\begin{array}{r}20 \\
3\end{array}$ & \begin{tabular}{|c}
12 \\
1
\end{tabular} & $\begin{array}{l}3 \\
1\end{array}$ & $\begin{array}{l}3 \\
0\end{array}$ & $\begin{array}{l}1 \\
0\end{array}$ & $\begin{array}{l}48 \\
11\end{array}$ & 59 \\
\hline $\begin{array}{l}231 \\
213\end{array}$ & $\begin{array}{r}14 \\
3\end{array}$ & $\begin{array}{r}15 \\
7\end{array}$ & $\begin{array}{r}13 \\
6\end{array}$ & $\begin{array}{l}2 \\
1\end{array}$ & $\begin{array}{l}3 \\
0\end{array}$ & $\begin{array}{l}1 \\
0\end{array}$ & $\begin{array}{l}48 \\
17\end{array}$ & 65 \\
\hline $\begin{array}{l}132 \\
123\end{array}$ & $\begin{array}{r}0 \\
10\end{array}$ & $\begin{array}{l}5 \\
7\end{array}$ & $\begin{array}{l}4 \\
4\end{array}$ & $\begin{array}{l}1 \\
2\end{array}$ & $\begin{array}{l}1 \\
0\end{array}$ & $\begin{array}{l}1 \\
1\end{array}$ & $\begin{array}{l}12 \\
34\end{array}$ & 46 \\
\hline
\end{tabular}

用いてきたが， 1.030以上では，屈折率の大きい尿素の 比率が增加するため，読みが見掛け上大きくなるといわ れる ${ }^{11}$ 。

2） Fishberg 氏濃縮試験の三分尿のいずれが最高尿

\section{滲透圧を示すか（表 1 ）}

早朝覚醒時排尿の第 1 尿から 1 時間後排尿の第 2 尿, 2 時間後排尿の第 3 尿へ順次尿渗透圧が上昇するのが予 想されるが，約 $1 / 4$ の症例では第 1 尿が最も高い渗透圧を 示し，第 2 尿が最高渗透圧を示するのは約 $1 / 3$ の症例にみ られている。

感情的ストレス, 或は寒冷で濃縮機能の低下が起ると いわれ ${ }^{12) 13)}$ ，この場合，感情，寒冷等の刺激が $\mathrm{ADH}$ 分 泌抑制を起するのと考学られる。

大島等 ${ }^{14)}$ によれば，20〜30才健康男子 100名の Fishberg 試験の結果, 第 1 尿より第 2 尿が 160〜 280mOsm $/ \mathrm{kgH}_{2} \mathrm{O}$ 高く，第 2 尿より第 3 尿が ${ }^{1} 1_{3}$ の症例で $20 \mathrm{mOsm}$ $/ \mathrm{kgH}_{2} \mathrm{O}$ 以上高く, 第 2 尿, 第 3 尿の採取のみで充分で あるとしている。然しこの結果は健康者に関するもので あり, 入院患者では, 不安, 緊張等の精神的ストレスが 大きく, 朝覚醒とともに濃縮機能の低下が起きて, 第 1 尿が最高值を示す症例があるのではないかと思われる． 従つて入院患者では従来通り 3 分尿について検查を行う ことが望しいと考えられる。

\section{3）最高尿滲透圧の再現性（図 3 ）}

$1 \sim 9$ 日の間隔で濃縮試験を反復した場合，最高尿滲 透圧はかなり変化する症例が多い。

これは上述のストレスの他に，摂取する蛋白量, 食塩 量の影響15) 18) 考光られるが，他方，12時間の飲食禁 止の条件では，全例に完全な濃縮状態に達しているとは 考えられず5)，飲食禁止開始直前の飲水状態が関係して くるのではないかと考党られる199。

いずれにせよ。再現性の必ずしも良くない点は, 濃縮 試験を例えば，数日連続して施行し最高值をとるとか， 领食禁止時間を延長するとかの改善をなすべきことを示
因 3 最高尿渗透圧の反復施行による変化

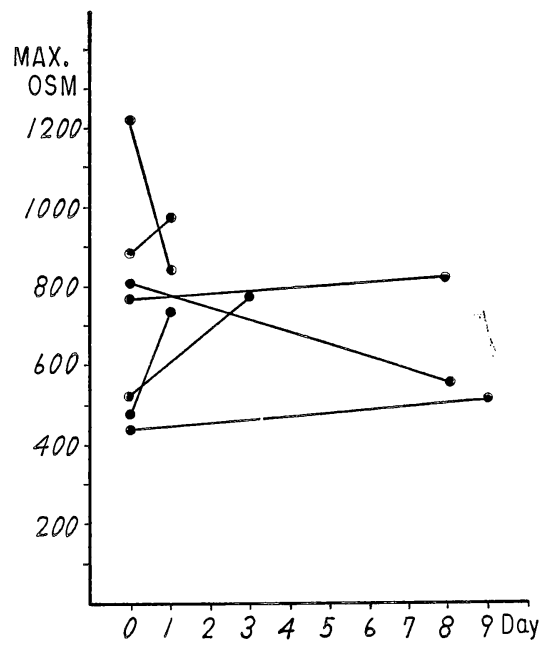

唆している。

このため, 最高尿滲透圧の症例毎の比較は危険がある ため，以下はいずれも群の結果を基に検討する。

4）最高尿滲透圧の正常範囲および年令による変化

(図 4, 図 5)

総腎機能正常と考号られる停留睪丸，尿道下裂等 23 例, 尿性器腫癔, 出血等26例, 偏腎疾患37例の計 114例 についての 最高尿滲透圧をみると，平均 $922 \mathrm{mOsm} / \mathrm{kg}$ $\mathrm{H}_{2} \mathrm{O}$ であり，年令別に分布を不ると，1才より10才未満 で最高値を示し，年令と共に順次低下を示している.

図 4 最高尿渗透圧の年令による変化

腎機能正常（副腎疾患。神経因性疾㭧，下部尿路閉 塞性疾患, 両腎疾患を除く) 及び偏腎疾患の患者群

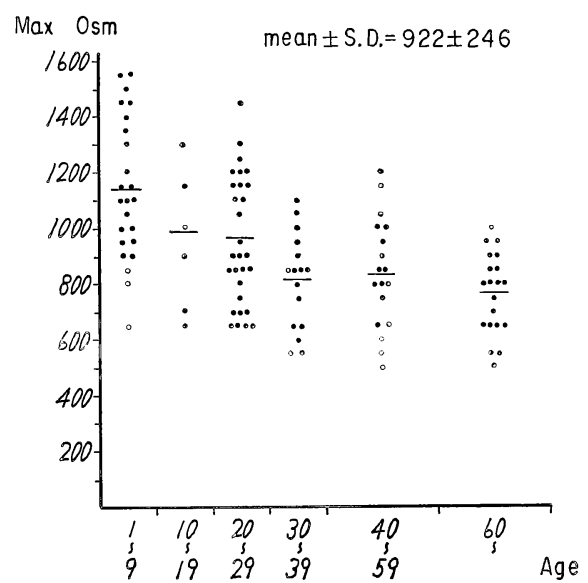


図 5 最高尿滲透圧の年令による変化 腎機能正常群 : 尿蛋白 (一), 高血圧 (一), 血清Ure$\mathrm{aN}<24 \mathrm{mg} / \mathrm{dl}$, P S P 2 時間值 $>50 \%$, 腎疾患 (一)

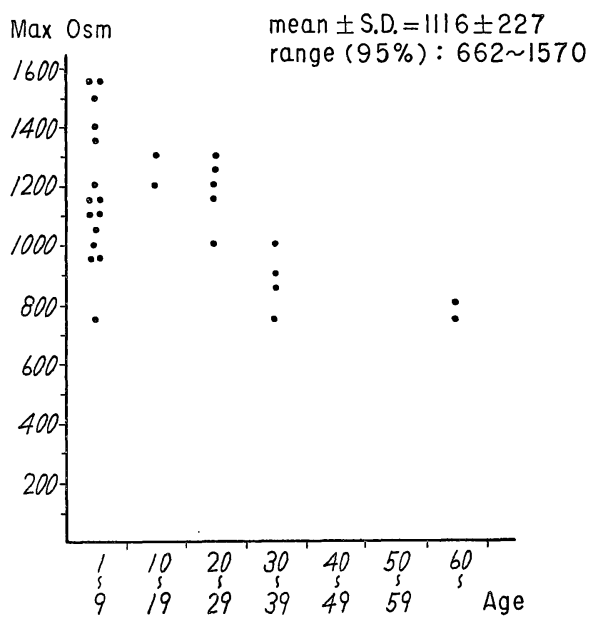

このらち, 尿蛋白, 高血圧, 腎疾患のいずれもなく, 腎機能正常である28例についてみると, 最高尿滲透圧の 平均は $1116 \mathrm{mOsm} / \mathrm{kgH}_{2} \mathrm{O}$ で, 95\%信頼限界は 662 15 $70 \mathrm{mOsm} / \mathrm{kgH}_{2} \mathrm{O}$ である.

これは腎機能正常の入院患者の最高尿滲透圧の一つの 目標となる数值であり，Fishberg 試験で約 700mOsm/ $\mathrm{kgH}_{2} \mathrm{O}$ まで達すれば，濃縮機能正常と判定しらると考 えられる。

最高尿滲透圧の正常範囲に関しては, 本邦では, 前述 の如く大島等 ${ }^{14)}$ によ，20〜30才健康男子 100 名の Fishberg 試験で, $1350 \pm 100 \mathrm{mOsm} / \mathrm{kgH}_{2} \mathrm{O}$ の結果が報 告され, 折田 ${ }^{18)}$ の報告では, 20才前後の女子 20 名の平均 は $1150 \mathrm{mOsm} / \mathrm{kgH}_{2} \mathrm{O}$ で, 少くとも $1000 \mathrm{mOsm} / \mathrm{kg} / \mathrm{H}_{2} \mathrm{O}$ 以上である.

これ等の報告と比較して吾々の結果が低值を示すの は, 入院患者であるためにストレス, 摂取蛋白量, 食塩 量が異なるためであろらと考えられる。

腎疾患のない入院患者の最高尿滲透圧の下限界は, 欧 米では約 $900 \mathrm{mOsm} / \mathrm{kgH}_{2} \mathrm{O}$ との報告が多いが8)2021)， 本邦人では下限界を約 $700 \mathrm{mOsm}^{\circ} \mathrm{kgH}_{2} \mathrm{O}$ に特くのが妥 当と考兄られる。

なを，年令による最高尿渗透圧の変化についての報告 は少い20)。

\section{5）最高尿滲透圧の疾患による変化（図 6）}

濃縮機能の面より対象疾患の分類を行うと, 腎正常群
図 6 疾患別の最高尿渗透圧（入院時）

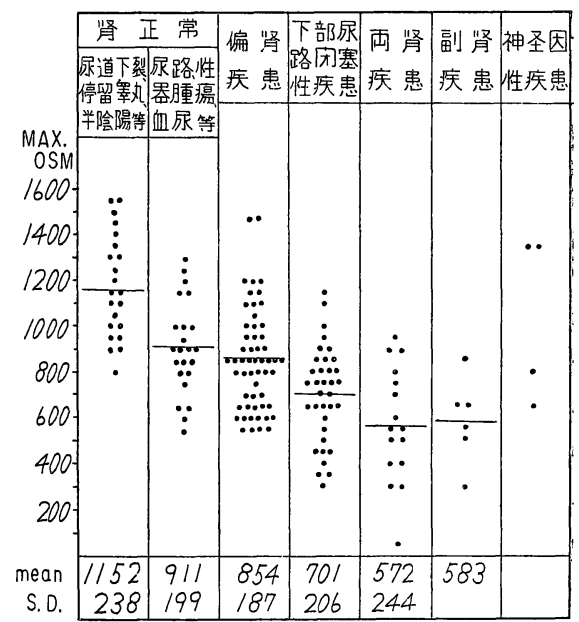

は尿道下裂, 停留睪丸, 尿性器腫湯等の 45 例, 偏腎疾患 群は腎結核, 腎尿管結石, 腎腫瘍, 水腎症等の55例, 下 部尿路閉塞性疾患群は前立腺肥大症等35例, 両腎疾患群 は両腎結石, 両腎結核, 慢性腎炎等の16例, 副腎疾患群 はアルドステロン症, クッシング症候群, 褐色細胞腫等 の 6 例, 神経因性疾患群は神経因性膀胱の 4 例である.

いずれの疾患群も，疾患の進行度に種々の程度がある ため，最高尿渗透圧にるばらつきが大さい。

正常群を, 尿道下裂, 停留梓丸等の群と, 尿性器腫瘍 等の群に分けると, 前者が後者より高値を示している。 これは前者では若年者が多いための結果と考兄られる。

偏腎疾患群では正常群と大差なく, 下部尿路閉塞性疾 患群ではやや低值を示し, 両腎疾患群, 副腎疾患群では 更に低值を示している。

濃縮機能障害の発生機序は, 腎病変によるカウンター カレント系障害, 尿細管の $\mathrm{ADH}$ への反応性の低下, および血中貯留物質増加とネフロン減少による滲透圧利 尿等が挙げられるが，各種疾患に拈ける濃縮能障害の病 態生理に関しては, Buchborn（1964）の綜説”がある。

6) 最高尿滲透圧之血清尿素窒素值との関係（図 7 ) 血清尿素窒素値の上昇と共に最高尿渗透圧の低下の傾 向がみられる。

血清尿素窒素值上昇は，扮打む水血清クレアチニン值 上昇と併行し，主としてGFR 低下に基くものである. GFR低下と共に最高尿渗透圧の低下 ${ }^{8222)}$, あるいは血清 尿素窒素値または血清クレアチニン值上昇とともに最高 尿渗透圧の低下 ${ }^{923)}{ }^{24)}$ 等の報告はなされている. 
図 7 最高尿滲透圧と血清尿素窒素值

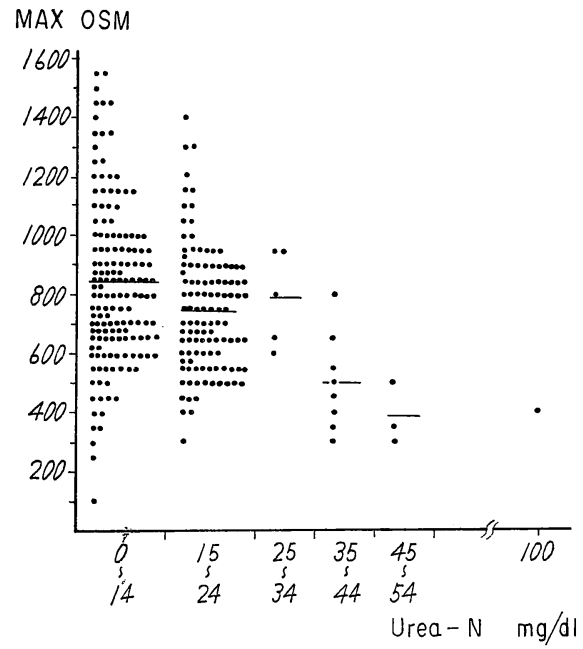

これ等の場合は，尿細管に対する溶質負荷量の増大に よる滲透圧利尿が最高尿滲透圧低下の大きな原因であ るので, 直ちにカウンターカレント系の障害あるいは $\mathrm{ADH}$ への反応性の低下を示すものではないと考えられ る。

7) 最高尿滲透圧と PSP 排泄試験との関係（図 8, 困 9)

PSP 排泄試験の15分值あるいは 2 時間值と最高尿滲 透圧との間には，明らかな相関関係は認められないが， PSP 排泄値の減少と共に最高尿渗透圧の低下する傾向 にある。

図 8 最高尿滲透圧と P S P 排泄值 (15分) との相 関

- 肾杜能正常、偏肾疾患

○下部尿路闭塞性疾患

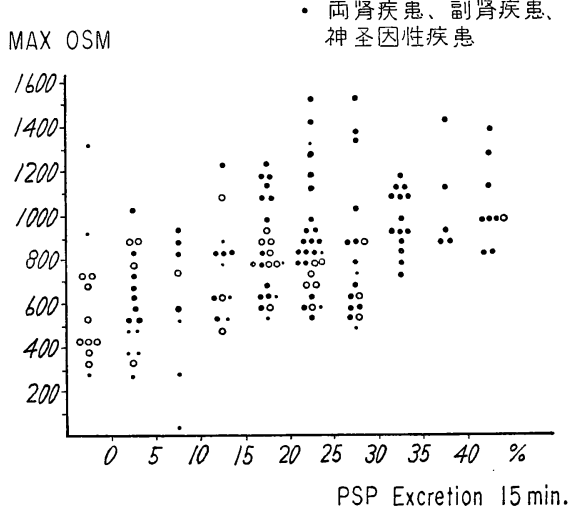

図 9 最高尿滲透圧と P S P 排泄值（2 時間）との 相関

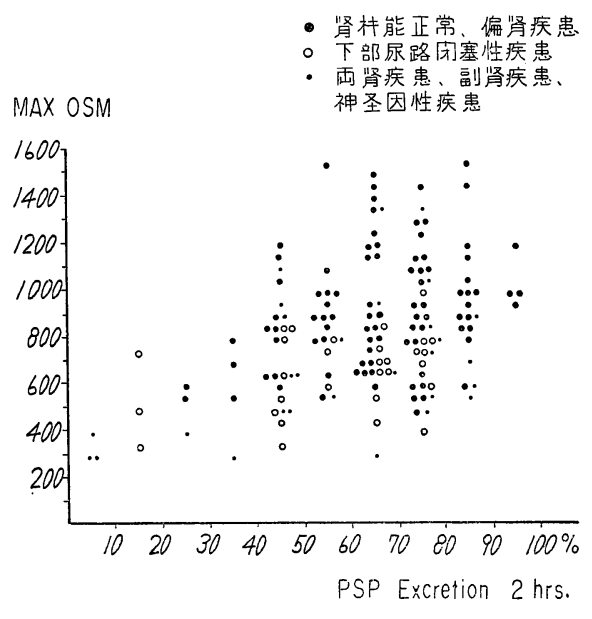

PSP 15分值はRPF と相関するものであるが，尿路 に死腔のある場合は見挂け上低值を示すものが多い。 PSP 2 時間值では RPF との相関は小さくなるが，死腔 の影響が比較的少いため, 最高尿滲透圧との関係るみる と，下部尿路閉塞性疾患群では，PSP 排泄值より最高尿 滲透圧の低下が腎正常群に比し高度である傾向がみられ る，両腎疾患群のらちにるこの傾向を示すものが多い. これは皮質機能よりも髄質機能の障害が高度であること を示し，尿路閉塞性疾患，腎血腎炎等に特徵的变化と考 えられる。

8）最高尿滲透圧の手術前後の変化（図10）

術後退院時の最高尿沴透圧は, 術前に比し, 手術の術 式，侵襲の大小等に関係なく殆んどの症例で低下してい る。

図10 最高尿滲透圧の術前後の変化

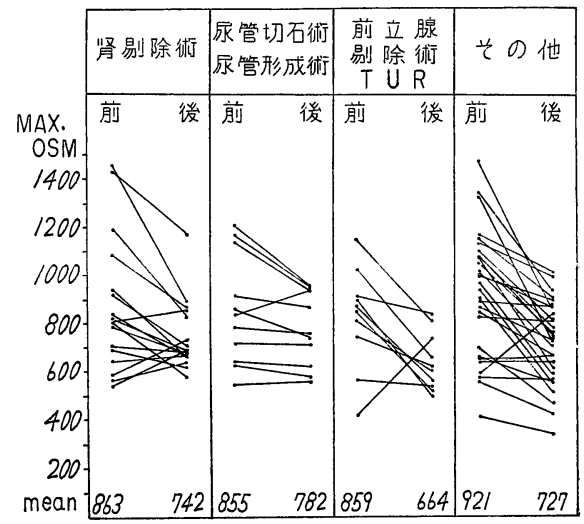


この原因は術後の栄養，ストレス等が関係するのでな いかと想像される。

手術中の 最高尿淩透圧が低下寸るとの報告があるが ${ }^{25)}$ ，この場合は，ADH への反応性の低下抽よび GFR 低下によるものと思われる。

腎䯣質機能の測定方法としての濃縮試験は, 渗透圧の 測定により定量的分析が可能になつたが，Fishberg 氏 法では再現性の点で若干改善の余地がある。

濃縮機能の検査法には, 最高尿渗透圧を求める所謂濃 縮試験と, $\mathrm{ADH}$ 投与とマニトール利尿により $\mathrm{T}_{\mathrm{m}}^{\mathrm{c}} \mathrm{H}_{2} \mathrm{O}$ を求める方法 ${ }^{6)}$ がある. 前者は種々の因子で容易に影響 をらけるが, 後者は再現性があり, かつ溶質排泄量の影 響をうけない。然し, 前者では血浆と尿との渗透圧勾配 が, 後者では集合管での単位時間に叔ける水の最大吸収 量が限界因子である．従つて，両者の間には若干意義の 相異があるものと思われる。

\section{結 論}

入院患者の Fishberg 濃縮試験の尿渗透圧を測定する ことにより次の結果を得た。

1）尿滲透圧と尿比重との間には, 相関係数 0.7 相 関関係がある。

2） Fishberg 試験の第 1 尿が 最高尿渗透圧を示す例 が約114にみられる。

3）最高尿渗透圧の再現性は必ずしもよくない.

4）腎機能正常者の最高尿渗透圧の下限界は $700 \mathrm{mOs}$ $\mathrm{m} / \mathrm{kgH}_{2} \mathrm{O}$ ある.

1〜10才で最高を示し，年令とともに低下する.

5）下部尿路閉塞性疾患, 両腎疾患, 副腎疾患では, 最高尿渗透圧は低下する。

6）血清尿素窒素值上昇とともに，最高尿滲透圧は低 下する.

7）PSP 排泄試験と最高尿渗透圧との間には明らかな 相関はないが, PSP 排泄值低下とともに最高尿渗透圧の 低下傾向がみられる。

下部尿路閉塞性疾患乱よび両腎疾患の一部では，PSP 排泄值よりも最高尿渗透圧の低下が高度である.

8）手術後は殆んどの例で最高尿渗透圧の低下がみら れる。

本論文の要旨は日本泌尿器科学会第 299 回東京地方会 に於て発表した。

なお，渗透圧測定に御協力戴いた村田㑆子氏に深謝致 します.:

\section{文献}

1) Gottschalk, C. W.: Am. J. Med. 36, 670, 1964.

2) Buchborn, E.: Schweiz. med. Wschr. 94, 1273, 1964.

3）高須照夫：内科, 12, 215, 1963.

4）前田貞扂 清水倉一：臨床病理, 13, 52, 1965.

5) Miles, ..E., A. Paton \& H.E. DeWardner : Brit. I :d. J. 1, 901, 1954.

6) Baldv n, D.S., H.J. Berman, H.O..Heineman \& Sr ith, H.W.: J. Clin. Invest. 34, 800, 1955

7) Fra .k, M.N., L.S. Dreifus, F. Rarick \& S. Beliet: Am. J. Med. Sci. 233, 121, 1957.

8) Mertz, D.P.: Zschr. Klin. Med. . 157, 517, $529,1963$.

9) Kaitz, A.L. \& A.M. London: Am. J. Med. $248,7,1964$.

10）上田泰, 高須照夫, 近藤昭, 花岡弘, 磯田一雄 : 日腎誌, 5, 100, 1963 .

11) 阿部裕：臨床病理, 10, 277, 1962.

12) Josephson, B. \& J. Ek: Advances in Clinical Chemistry, 1, 41, 1958.

13）吉利和, 大島研三, 上田泰, 他 : 日腎誌, 8,58 , 1966.

14）大島研三, 上田泰, 吉利和, 他 : 日腎誌, 6,118 , 1964.

15) Epstein, F.H., C.R. Kleeman, S. Parsel \& A. Hendrikx: J. Clin. Invest. 36, 635, 1957.

16) House, E.W., E.W. Pfeiffer \& H.A. Braun: Nature, 199, 181, 1963.

17) Jick, H., R.H. Sweet, W. Smith, K. Macgaffey, J.G., Snyder \& E.D. Moore: Clin. Sci. 26, 397,1964.

18）折田義正：日腎誌， $7,113,1965$.

19) Epstein, F.H., C.R. Kleeman \& A. Hendrikx: J. Clin. Invest. 36, 629, 1957.

20) Lindeman, R.D., H.C. VanBuren \& L.G. Raisz: New Engl. J. Med. 262, 1306, 1960.

21) Boyarsky, S. \& H.W. Smith: J. Urol. 78, $511,1957$.

22) Levinsky. N.G.: J. Clin. Invest. 38, 730, 1959

23) Bricker, N.S., R.R. Dewey, H. Lubowitz, J. Stokes \& T. Kirkensgaard: J. Clin. Invest. 38, 516, 1959.

24) Kleeman, C.R., W.L. Hewitt \& L.B. Guze: Medicine, 39, 3, 1960.

25) Gullick, J.D. \& L.G. Raisz: New Engl. J. Med. 262, 1309, 1960.

（昭和 41 年 8 月 30 日受付） 